\title{
Chiral Fluorescence Polyethers Based on BINOL for Enantioselective Recognition of Phenylalanine Anion
}

\author{
Chunhui Zhao, Kunbing Ouyang*, Jin Zhang and Nianfa Yang* \\ Key Laboratory of Environmentally Friendly Chemistry and Applications of Ministry of Education, \\ College of Chemistry, Xiangtan University, Xiangtan 411105, China. \\ *Corresponding author E-mails: kbouyang@xtu.edu.cn, nfyang@xtu.edu.cn
}

\begin{abstract}
Series of polyethers with different configurations were synthesized from chiral BINOL and optical epichlorohydrin. The optical behavior of the obtained polyethers is evaluated with specific optical rotation, UV-vis spectroscopy, circular dichroism (CD) and fluorescence spectroscopy. Thermogravimetric analysis (TGA) reveals the polyethers a good thermal stability. The fluorescence responses of the chiral polyethers on chiral phenylalanine anion were investigated. The sensors $(S, S)-\mathbf{4}$ and $(R, R)-\mathbf{4}$ showed high enantioselective fluorescent sensing ability to phenylalanine anion. The value of enantiomeric fluorescence difference ratio $(e f)$ reached to 6.29 .
\end{abstract}

KEYWORDS: chiral polyether, fluorescence enantioselective recognition, phenylalanine anion.

\section{INTRODUCTION}

Enantioselective recognition of chiral molecules by host compounds is an attractive topic for its vital role in asymmetric synthesis and biological systems. ${ }^{1-4}$ Among the countless chiral substances, $\alpha$-amino acids are the most common and basic enantiomers. Enantioselective recognition of $\alpha$-amino acids attracted considerable interest due to their importance in nature. ${ }^{5-11}$ Various techniques, including high-performance liquid chromatography (HPLC), nuclear magnetic resonance (NMR), UV/vis, circular dichroism (CD) and fluorescence spectroscopy have been applied to the discrimination and analysis of enantiomers. ${ }^{12-15}$ Enantioselective fluorescent sensors are receiving growing research attention as they potentially provide a real time technique to analysis the enantiomeric composition of chiral organic compounds. ${ }^{16-22}$ Although great development of fluorescent sensors has been achieved, enantioselective fluorescent sensors for structurally diverse chiral $\alpha$-amino acids still remain challenges in this area due to the zwitterionic property of the $\alpha$-amino acids, which results in their very slight solubility in organic solvents and little interaction with organic fluorophores in water. ${ }^{23-26}$ Series of fluorescent sensors, most of which are based on chiral small molecules, have been studied. ${ }^{27-31}$ Chiral polymers used as fluorescence-based sensors for enantioselective recognition of chiral molecules offer several advantages over small molecule sensors, such as fluorescence efficiency enhancement and possible cooperative effects of multiple chiral units. ${ }^{32-35}$

In this work, we synthesized a series of polyethers derived from chiral BINOL and optical epichlorohydrin. The BINOL plays the role of fluorophore, scaffold and the chiral center. The long chain of ether band brings the polymers superior solubility, which allows us to conduct our research in a mixed solvent of THF and water. The fluorescence responses of the obtained polyethers on chiral phenylalanine anions were investigated by fluorescence spectra in $\mathrm{THF} / \mathrm{H}_{2} \mathrm{O}$ system, The sensors $(S, S)-\mathbf{4}$ and $(R, R)-\mathbf{4}$ were found to show high enantioselective fluorescent sensing ability to phenylalanine anion. The value of enantiomeric fluorescence difference ratio (ef) reaches to 6.29, 
makes $(S, S)-\mathbf{4}$ and $(R, R)-\mathbf{4}$ practically useful sensors for the recognition of the chiral phenylalanine anion.

\section{EXPERIMENTAL}

\section{Reagents and instrumentation}

All solvents and reagents are commercially available and analytical-reagent-grade. Optically active epichlorohydrin (ECH) was purchased from Yueyang Branch Company, Shenzhen Yawangkang Technology Co., Ltd. Toluene were purified by distillation from sodium in the presence of benzophenone. NMR spectra were measured on Bruker $\mathrm{ARX} 400 \mathrm{MHz}$ spectrometer using $\mathrm{CDCl}_{3}$ as solvent and tetramethylsilane (TMS) as internal standard. Optical rotation data were measured on a Perkin Elmer Model 341 LC Polarimeter at $365 \mathrm{~nm}$. Elemental analyses were carried out on Elementar Vario EL instrument. GPC analyses were performed with a JASCO-GPC system consisting of DG-1580-53 degasser, PU-980 HPLC pump, UV-970 UV/Vis detector, RI-930 RI detector, and CO-2065-plus column oven (at $38^{\circ} \mathrm{C}$ ) using two connected Shodex GPC-KF-804L columns in THF (sample concentration $=1 \mathrm{wt} \%$; flow rate $=1.0 \mathrm{~mL} / \mathrm{min}$ ). The molecular weight was calibrated with commercially available polystyrene. The fluorescence measurements were done on a Shimadzu RF-5301PC spectrofluorimeter. UV-vis spectra were obtained with a Shimadzu UV-2450 spectrophotometer. Thermal gravimetric analysis was conducted on a thermogravimetric analyzer (TGA Q50, TA instrumen, USA).

\section{Synthesis of chiral 2-glycidyloxy-2'-methoxymethyloxy-1,1'-binaphthalene, (monomer 2)}

2'-(methoxymethoxy)-[1,1'-binaphthalen]-2-ol, (1) $(S$ or $R$ ) (3.30 g, $10 \mathrm{mmol})$, powder potassium hydroxide (KOH) $(1.12 \mathrm{~g}, 20 \mathrm{mmol})$, tetrabutylammonium bromide (TBAB) $(0.32 \mathrm{~g}, 1 \mathrm{mmol})$ and 50 $\mathrm{mL}$ THF were added in a $100 \mathrm{~mL}$ round-bottom flask. The mixture was stirred for 10 minutes at room temperature. $(S)$-ECH or $(R)$-ECH or racemic ECH $(1.39 \mathrm{~g}, 15 \mathrm{mmol})$ was added and the mixture was stirred at the same temperature for another $20 \mathrm{~h}$. Solvent was evaporated under reduced pressure and the residue was diluted with ethyl acetate $(50 \mathrm{~mL})$. The ethyl acetate solution was washed with water. The water layer was extracted with ethyl acetate $(3 \times 20 \mathrm{~mL})$ and the combined organic layer was dried over $\mathrm{Na}_{2} \mathrm{SO}_{4}$. Flash column chromatography (petroleum ether/ethyl acetate $=3 / 1$ ) was performed carefully on silica gel to give compound 2 (colorless oil, yield 94-96\%).

$(S, S)$-2, yield 94\%. $[\alpha]_{365}^{20}=-669.0(\mathrm{c}=1.0, \mathrm{THF}) .{ }^{1} \mathrm{H}$ NMR $\delta: 7.95(\mathrm{~d}, J=8.7 \mathrm{~Hz}, 2 \mathrm{H}), 7.87(\mathrm{~d}, J=$ $7.6 \mathrm{~Hz}, 2 \mathrm{H}), 7.57$ (d, $J=8.9 \mathrm{~Hz}, 1 \mathrm{H}), 7.44(\mathrm{~d}, J=8.9 \mathrm{~Hz}, 1 \mathrm{H}), 7.34(\mathrm{t}, J=7.0 \mathrm{~Hz}, 2 \mathrm{H}), 7.18(\mathrm{~s}, 2 \mathrm{H})$, $7.17-7.08(\mathrm{~m}, 2 \mathrm{H}), 5.09$ (d, $J=6.5 \mathrm{~Hz}, 1 \mathrm{H}), 4.98(\mathrm{~d}, J=6.7 \mathrm{~Hz}, 1 \mathrm{H}), 4.07(\mathrm{~d}, J=11.2 \mathrm{~Hz}, 1 \mathrm{H}), 4.00$ (dd, $J=11.2,4.7 \mathrm{~Hz}, 1 \mathrm{H}), 3.16(\mathrm{~s}, 3 \mathrm{H}), 2.94(\mathrm{~s}, 1 \mathrm{H}), 2.55$ (s, $1 \mathrm{H}), 2.30(\mathrm{~s}, 1 \mathrm{H}) .{ }^{13} \mathrm{C}$ NMR $\delta: 154.25$, $152.93,134.21,134.14,130.01,129.81,129.67,129.58,128.10,128.09,126.57,126.44,125.69$, 125.59, 124.16, 124.13, 121.12, 121.05, 117.37, 116.34, 95.35, 70.62, 55.94, 50.37, 44.50. Elem. Anal. Calcd. for $\mathrm{C}_{25} \mathrm{H}_{22} \mathrm{O}_{4}$ : C, 77.70; H, 5.74. Found: $\mathrm{C}, 77.75 ; \mathrm{H}, 5.76$.

$(S, R)-2$, yield 95\%. $[\alpha]_{365}^{20}=-741.0(\mathrm{c}=1.0, \mathrm{THF}) .{ }^{1} \mathrm{H}$ NMR $\delta: 7.97-7.94(\mathrm{~m}, 2 \mathrm{H}), 7.88(\mathrm{~d}, J=6.2$ $\mathrm{Hz}, 2 \mathrm{H}), 7.58(\mathrm{~d}, J=8.9 \mathrm{~Hz}, 1 \mathrm{H}), 7.46(\mathrm{~d}, J=8.9 \mathrm{~Hz}, 1 \mathrm{H}), 7.34(\mathrm{~d}, J=6.8 \mathrm{~Hz}, 2 \mathrm{H}), 7.22-7.12(\mathrm{~m}$, 4H), $5.08(\mathrm{~s}, 1 \mathrm{H}), 4.97(\mathrm{~d}, J=6.4 \mathrm{~Hz}, 1 \mathrm{H}), 4.16-4.12(\mathrm{~m}, 1 \mathrm{H}), 4.03-3.99(\mathrm{~m}, 1 \mathrm{H}), 3.16(\mathrm{~s}, 3 \mathrm{H}), 2.95$ (s, 1H), $2.55-2.51(\mathrm{~m}, 1 \mathrm{H}), 2.30$ (s, 1H). ${ }^{13} \mathrm{C}$ NMR $\delta$ : 154.14, 152.96, 134.24, 134.17, 130.33, 129.81, $129.69,129.60,128.13,126.60,126.50,125.69,125.62,124.20,124.15,121.16,121.01,117.40$, 116.23, 95.38, 69.95, 55.94, 50.39, 44.32. Elem. Anal. Calcd. for $\mathrm{C}_{25} \mathrm{H}_{22} \mathrm{O}_{4}$ : C, 77.70; H, 5.74. Found: C, 77.73; H, 5.78 . 
$(S)-2$, yield 95\%. $[\alpha]_{365}^{20}=-513(\mathrm{c}=1.0, \mathrm{THF}) .{ }^{1} \mathrm{H}$ NMR $\delta: 7.95(\mathrm{dd}, J=8.9,3.1 \mathrm{~Hz}, 2 \mathrm{H}), 7.87(\mathrm{~d}, J$ $=7.2 \mathrm{~Hz}, 2 \mathrm{H}), 7.57(\mathrm{dd}, J=9.0,1.5 \mathrm{~Hz}, 1 \mathrm{H}), 7.44(\mathrm{dd}, J=9.0,3.4 \mathrm{~Hz}, 1 \mathrm{H}), 7.34(\mathrm{t}, J=7.4 \mathrm{~Hz}, 2 \mathrm{H})$, $7.17(\mathrm{ddd}, J=20.9,10.1,5.4 \mathrm{~Hz}, 4 \mathrm{H}), 5.08(\mathrm{dd}, J=6.7,3.8 \mathrm{~Hz}, 1 \mathrm{H}), 4.97(\mathrm{dd}, J=9.6,6.8 \mathrm{~Hz}, 1 \mathrm{H})$, $4.16-4.05(\mathrm{~m}, 1 \mathrm{H}), 4.00(\mathrm{dd}, J=11.3,4.7 \mathrm{~Hz}, 1 \mathrm{H}), 3.16(\mathrm{~d}, J=5.5 \mathrm{~Hz}, 3 \mathrm{H}), 2.94(\mathrm{~s}, 1 \mathrm{H}), 2.54(\mathrm{dt}, J=$ 9.0, 4.6 Hz, 1H), $2.30(\mathrm{dd}, J=4.9,2.5 \mathrm{~Hz}, 1 \mathrm{H}) .{ }^{13} \mathrm{C} \mathrm{NMR} \delta: 154.05,152.83,134.14,134.06,129.96$, 129.60, 129.52, 128.00, 126.51, 126.41, 125.63, 125.54, 124.10, 121.08, 117.38, 116.41, 116.28, 95.37, 70.66, 70.05, 55.94, 50.39, 50.36, 44.58, 44.41. Elem. Anal. Calcd. for $\mathrm{C}_{25} \mathrm{H}_{22} \mathrm{O}_{4}$ : C, 77.70; H, 5.74. Found: C, 77.72; H, 5.75 .

$(R, R)-2$, yield 94\%. $[\alpha]_{365}^{20}=+661(\mathrm{c}=1.0, \mathrm{THF}) .{ }^{1} \mathrm{H}$ NMR $\delta: 7.95(\mathrm{dd}, J=8.9,2.4 \mathrm{~Hz}, 2 \mathrm{H}), 7.87(\mathrm{~d}$, $J=7.7 \mathrm{~Hz}, 2 \mathrm{H}), 7.57(\mathrm{~d}, J=9.0 \mathrm{~Hz}, 1 \mathrm{H}), 7.45-7.42(\mathrm{~m}, 1 \mathrm{H}), 7.34(\mathrm{t}, J=7.4 \mathrm{~Hz}, 2 \mathrm{H}), 7.22-7.10(\mathrm{~m}$, $4 \mathrm{H}), 5.08(\mathrm{dd}, J=6.5,3.8 \mathrm{~Hz}, 1 \mathrm{H}), 4.99-4.97(\mathrm{~m}, 1 \mathrm{H}), 4.07(\mathrm{dd}, J=11.4,3.4 \mathrm{~Hz}, 1 \mathrm{H}), 4.00(\mathrm{~d}, J=$ $6.4 \mathrm{~Hz}, 1 \mathrm{H}), 3.16(\mathrm{~s}, 3 \mathrm{H}), 2.94(\mathrm{~s}, 1 \mathrm{H}), 2.56-2.53(\mathrm{~m}, 1 \mathrm{H}), 2.31-2.28(\mathrm{~m}, 1 \mathrm{H}) .{ }^{13} \mathrm{C} \mathrm{NMR} \delta: 154.03$, 152.72 , 133.99, 133.93, 129.80, 129.80, 129.59, 129.47, 129.38, 127.89, 126.37, 126.24, 125.47, 125.38, 123.96, 123.93, 120.88, 120.79, 117.14, 116.09, 115.99, 95.12, 70.39, 55.73, 50.16, 44.28. Elem. Anal. Calcd. for $\mathrm{C}_{25} \mathrm{H}_{22} \mathrm{O}_{4}$ : C, 77.70; H, 5.74. Found: C, 77.77; H, 5.77.

$(R, S)-2$, yield 96\%. $[\alpha]_{365}^{20}=+735(\mathrm{c}=1.0, \mathrm{THF}) .{ }^{1} \mathrm{H}$ NMR $\delta: 7.95-7.92(\mathrm{~m}, 2 \mathrm{H}), 7.86(\mathrm{~d}, J=6.4$ $\mathrm{Hz}, 2 \mathrm{H}), 7.56(\mathrm{~d}, J=9.0 \mathrm{~Hz}, 1 \mathrm{H}), 7.43(\mathrm{dd}, J=9.0,3.4 \mathrm{~Hz}, 1 \mathrm{H}), 7.33(\mathrm{t}, J=7.3 \mathrm{~Hz}, 2 \mathrm{H}), 7.21-7.10$ $(\mathrm{m}, 4 \mathrm{H}), 5.08-5.05(\mathrm{~m}, 1 \mathrm{H}), 4.95(\mathrm{t}, J=4.7 \mathrm{~Hz}, 1 \mathrm{H}), 4.14(\mathrm{dd}, J=11.6,3.1 \mathrm{~Hz}, 1 \mathrm{H}), 3.98(\mathrm{~d}, J=6.7$ $\mathrm{Hz}, 1 \mathrm{H}), 3.14(\mathrm{~s}, 3 \mathrm{H}), 2.93(\mathrm{~s}, 1 \mathrm{H}), 2.52(\mathrm{dd}, J=9.5,4.6 \mathrm{~Hz}, 1 \mathrm{H}), 2.31-2.27(\mathrm{~m}, 1 \mathrm{H}) .{ }^{13} \mathrm{C}$ NMR $\delta$ : $153.96,152.75,134.05,133.97,129.87,129.87,129.65,129.53,129.44,127.93,126.42,126.33$, 125.52, 125.47, 124.04, 124.00, 121.03, 120.89, 117.28, 116.14, 95.29, 69.91, 55.83, 50.29, 44.27. Elem. Anal. Calcd. for $\mathrm{C}_{25} \mathrm{H}_{22} \mathrm{O}_{4}$ : C, 77.70; H, 5.74. Found: C, 77.74; H, 5.78.

$(R)-2$, yield 95\%. $[\alpha]_{365}^{20}=+526(\mathrm{c}=1.0, \mathrm{THF}) .{ }^{1} \mathrm{H}$ NMR $\delta: 7.95(\mathrm{~d}, J=8.7 \mathrm{~Hz}, 2 \mathrm{H}), 7.87(\mathrm{~d}, J=7.5$ $\mathrm{Hz}, 2 \mathrm{H}), 7.57(\mathrm{~d}, J=9.0 \mathrm{~Hz}, 1 \mathrm{H}), 7.44(\mathrm{~d}, J=8.8 \mathrm{~Hz}, 1 \mathrm{H}), 7.34(\mathrm{t}, J=6.7 \mathrm{~Hz}, 2 \mathrm{H}), 7.24-7.10(\mathrm{~m}$, $4 \mathrm{H}), 5.08(\mathrm{~d}, J=3.6 \mathrm{~Hz}, 1 \mathrm{H}), 4.97(\mathrm{t}, J=7.6 \mathrm{~Hz}, 1 \mathrm{H}), 4.13(\mathrm{t}, J=13.4 \mathrm{~Hz}, 1 \mathrm{H}), 4.00(\mathrm{dd}, J=11.0,4.4$ $\mathrm{Hz}, 1 \mathrm{H}), 3.15(\mathrm{~d}, J=4.1 \mathrm{~Hz}, 3 \mathrm{H}), 2.94(\mathrm{~s}, 1 \mathrm{H}), 2.57-2.51(\mathrm{~m}, 1 \mathrm{H}), 2.30(\mathrm{~s}, 1 \mathrm{H}) .{ }^{13} \mathrm{C} \mathrm{NMR} \delta: 154.57$, $154.44,153.24,134.53,134.46,130.35,130.16,130.13,130.00,129.91,128.41,126.90,126.80$, 126.77, 126.03, 126.01, 125.93, 124.50, 121.51, 121.39, 117.75, 117.73, 116.74, 116.62, 95.76, 95.73, 71.01, 70.38, 56.31, 50.76, 50.73, 44.92,44.75. Elem. Anal. Calcd. for $\mathrm{C}_{25} \mathrm{H}_{22} \mathrm{O}_{4}$ : C, 77.70; H, 5.74. Found: C, 77.76; H, 5.75.

Preparation of poly-2-glycidyloxy-2'-methoxymethyloxy-1,1'-binaphthalene, (polyether 3)

A test tube with a stirrer bar was charged with $1.92 \mathrm{~g}(5.00 \mathrm{mmol})$ of epoxide monomer $2,0.2 \mathrm{mmol}$ of $\mathrm{KOH}$ and $1 \mathrm{~mL}$ degassed toluene under an argon atmosphere, and then sealed with the flame of a Bunsen burner. The test tube was put into an oil bath thermostat at $110{ }^{\circ} \mathrm{C}$. The reaction mixture was then stirred for $24 \mathrm{~h}$. The reaction mixture was then cooled to room temperature and the tube was opened. Next, $10 \mathrm{~mL}$ THF was added to give a homogenous solution. The THF solution was poured into $100 \mathrm{~mL}$ methanol to precipitate the white polymer. The resulting polymer was filtrated and washed with methanol several times. The above mentioned process, that is, the solving and precipitating, was repeated, then the obtained precipitation was dried in vacuo at $50{ }^{\circ} \mathrm{C}$ to obtain polyether 3 (white powder, yield 74-77\%). ${ }^{1} \mathrm{H}$ NMR $\delta: 7.90-6.76(\mathrm{br}, 12 \mathrm{H}, \mathrm{Ar}-\mathrm{H}), 5.01-4.43\left(\mathrm{br}, 2 \mathrm{H},-\mathrm{O}-\mathrm{CH}_{2}-\mathrm{O}-\right.$ ), $3.75-3.20$ (br, $2 \mathrm{H}, \mathrm{O}-\mathrm{CH}_{2}-$ ), $3.15-2.15$ (br, $\left.6 \mathrm{H},-\mathrm{CH}_{2}-\mathrm{O},-\mathrm{O}-\mathrm{CH}_{3},>\mathrm{CH}-\mathrm{O}\right) .{ }^{13} \mathrm{C}$ NMR $\delta: 154.09$, 152.62 , 134.06, 129.68, 129.39, 129.24, 127.97, 126.33, 125.40, 123.98, 123.62, 121.22, 119.69, 
117.07, 115.01, 94.90, 69.04, 55.67.

\section{Preparation of poly-2-glycidyloxy-[1,1'-binaphthalen]-2-ol, (polyether 4)}

$1.05 \mathrm{~g}$ polyether 3 was dissolved in a mixture solvent $(35 \mathrm{~mL}$ THF and $10 \mathrm{~mL} 12 \mathrm{M} \mathrm{HCl})$. The mixture was stirred for $24 \mathrm{~h}$ at room temperature. Then the mixture was poured into $350 \mathrm{~mL}$ methanol to precipitate the white polymer. The resulting polymer was filtrated and washed with methanol several times. The obtained precipitation was dried in vacuo at $50{ }^{\circ} \mathrm{C}$ to obtain polyether 4 (white powder, yield 94-97\%). ${ }^{1} \mathrm{H}$ NMR $\delta$ : $7.97-6.59$ (br, 12H, Ar-H), $6.02-5.19$ (br, 1H, -OH), $3.69-3.17$ (br, 2H, $-\mathrm{O}-\mathrm{CH}_{2}-$ ), $2.89-2.08$ (br, 3H, $\left.-\mathrm{CH}_{2}-\mathrm{O},>\mathrm{CH}-\mathrm{O}\right) .{ }^{13} \mathrm{C}$ NMR $\delta: 154.75,151.46,134.10,130.44$, $129.48,128.96,128.21,128.06,127.09,126.44,125.20,125.01,124.14,123.24,118.09,115.87$, $114.98,77.60,68.02$.

\section{Preparation of the test samples}

The host compounds 4 were dissolved in a THF/ $\mathrm{H}_{2} \mathrm{O}$ system $(1: 1,0.01 \mathrm{M}$ Tris - $\mathrm{HCl}$ buffer, $\mathrm{pH} 7.4)$ as stock solutions. The tetrabutylammonium salts were prepared by adding 1 equiv. of tetrabutylammonium hydroxide to a solution of $(D)$ - or $(L)$-phenylalanine the in methanol and stirred for $2 \mathrm{~h}$. After removing the methanol under reduced pressure, the syrup was dried under high vacuum for $24 \mathrm{~h}$ and prepared as stock solutions in a THF/ $\mathrm{H}_{2} \mathrm{O}$ system $(1: 1,0.01 \mathrm{M}$ Tris - $\mathrm{HCl}$ buffer, $\mathrm{pH} 7.4)$. The test solutions were prepared by mixing desired volumes of anion solution to a series of stock solution of the host compound.

\section{RESULTS AND DISCUSSION}

\section{Synthesis}

Chiral polymer sensors were synthesized according to Scheme 1 . The reaction of compound $\mathbf{1}$ and ECH catalyzed by $\mathrm{KOH}$ and TBAB gives monomer 2 with pretty high yields 94-96\%. Polyether 3 was obtained with the yields varied from $74 \%$ to $77 \%$ by anionic polymerizations of 2 initiated by KOH. Polyether $\mathbf{4}$ were efficiently prepared by deprotection of $\mathbf{3}$ also with high yields $94-97 \%$.

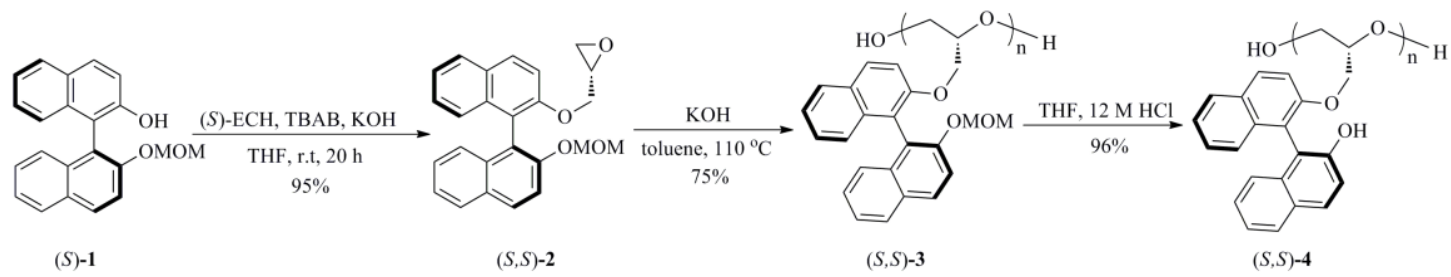

Scheme 1. The synthetic route for the monomers 2 and polyethers 3 and 4 .

The data of the synthesized compounds are shown in Table 1. The $\mathbf{M}_{n}$ of polyether $\mathbf{3}$ was 3300-3800, about 9 or 10 repeat units. The deprotection of MOM group made the $M_{n}$ of polyether 4 normally decreased to 3000-3400. Both polyether $\mathbf{3}$ and $\mathbf{4}$ have narrow molecular weight distribution, the PDI changes from 1.24 to 1.30 . The specific optical rotation of the obtained compounds $\mathbf{2}, \mathbf{3}$ and $\mathbf{4}$ show that $(S)$-BINOL gives the obtained compounds negative rotation, when $(R)$-BINOL was used, the compounds all showed positive rotation. The rotation increased a little after deprotection when it compared of $\mathbf{3}$ and $\mathbf{4}$ with the same configuration.

Table 1.Anionic polymerizations of epoxide monomers ${ }^{\text {a }}$

\begin{tabular}{|c|c|c|c|c|c|c|c|c|c|c|}
\hline \multirow{2}{*}{ Conf. } & \multicolumn{2}{|c|}{ Monomers 2} & \multicolumn{4}{|c|}{ Protected-polyether $\mathbf{3}$} & \multicolumn{4}{|c|}{ Deprotected-polyether 4} \\
\hline & Yield & {$[a]_{365}^{20} \mathrm{~b}$} & Yield & {$[a]_{365}^{20} \mathrm{~b}$} & $\mathrm{M}_{\mathrm{n}}$ & PDI & Yield & {$[\mathrm{a}]_{365}^{20 \mathrm{~b}}$} & $\mathrm{M}_{\mathrm{n}}$ & PDI \\
\hline
\end{tabular}




\begin{tabular}{ccccccccccc}
\hline & $1 \%^{\mathrm{a}}$ & & $1 \%^{\mathrm{a}}$ & & & $\left(\mathrm{M}_{\mathrm{w}} / \mathrm{M}_{\mathrm{n}}\right)^{\mathrm{c}}$ & $1 \%^{\mathrm{a}}$ & & & $\left(\mathrm{M}_{\mathrm{w}} / \mathrm{M}_{\mathrm{n}}\right)^{\mathrm{c}}$ \\
\hline$(S, S)$ & 94 & -669 & 75 & -906 & 3357 & 1.25 & 96 & -986 & 3076 & 1.24 \\
$(S, R)$ & 95 & -741 & 77 & -716 & 3856 & 1.28 & 94 & -776 & 3415 & 1.26 \\
$(S)$ & 95 & -513 & 76 & -855 & 3413 & 1.29 & 96 & -889 & 3024 & 1.27 \\
$(R, R)$ & 94 & +661 & 77 & +896 & 3349 & 1.27 & 97 & +979 & 2967 & 1.24 \\
$(R, S)$ & 96 & +735 & 74 & +730 & 3783 & 1.25 & 94 & +781 & 3352 & 1.24 \\
$(R)$ & 95 & +526 & 77 & +838 & 3381 & 1.30 & 97 & +878 & 2993 & 1.26 \\
\hline
\end{tabular}

${ }^{\mathrm{a}}$ The polyethers were obtained by bulk polymerization for $24 \mathrm{~h}$ at $110{ }^{\circ} \mathrm{C}$ using $\mathrm{KOH}$ as an initiator, $[\mathrm{M}] /[\mathrm{I}]=25: 1 .{ }^{\mathrm{b}} \mathrm{c}$ $=1.0 \mathrm{mg} \cdot \mathrm{mL}^{-1}$ in THF. ${ }^{\mathrm{c}}$ Number-average molar mass $\left(\mathrm{M}_{\mathrm{n}}\right)$, weight-average molar mass $\left(\mathrm{M}_{\mathrm{w}}\right)$, and polydispersity $\left(\mathrm{M}_{\mathrm{w}} / \mathrm{M}_{\mathrm{n}}\right)$ were determined by GPC in THF on the basis of standard polystyrene calibration.

The CD spectroscopy was used to further characterize the chiroptical properties of $\mathbf{2}, \mathbf{3}$ and $\mathbf{4}$. As is shown in Supplementary Information Part 2, all the compounds absorbed intensively at 244nm, indicating the electronic transitions of BINOL group. Another two opposite weak peaks were at $288 \mathrm{~nm}$ and 319nm. Mirror images were observed in the CD spectra when different configuration of BINOL was used. Comparing with the same configuration compounds such as $(S, S)-\mathbf{2},(S, S)-\mathbf{3}$ and $(S, S)-\mathbf{4}$, the CD spectra of $2,3,4$ were almost the same, revealing that no other chiral centers were formed in the polymerization and deprotection process.

Thermogravimetric analysis (TGA) of $(R, R)-\mathbf{4}$ was carried out (Supplementary Information Part 3). The high decomposition temperature $325^{\circ} \mathrm{C}$ reveals the polyether $(R, R)-\mathbf{4}$ excellent thermal stability.

\section{Fluorescence spectra study}

The fluorescence response behavior of the chiral polyether on $(D)$ - or $(L)$-phenylalanine anions were investigated in a solution $\left(1: 1 \mathrm{THF} / \mathrm{H}_{2} \mathrm{O}, 0.01 \mathrm{~mol} \cdot \mathrm{L}^{-1}\right.$ Tris- $\mathrm{HCl}$ buffer, $\left.\mathrm{pH}=7.4\right)$ of 4 and enantiomers phenylalanine anions (as tetrabutylammonium salts). As expected, the dilute solution of $(S, S)-4$ had low fluorescence at $364 \mathrm{~nm}$. We first examined the fluorescent response of chiral polyether $(S, S)-\mathbf{4}$ on $(D)$ and $(L)$-phenylalanine anions. $(D)$-phenylalanine anion causes a large increase in the fluorescence intensity of $(S, S)-4$ at $364 \mathrm{~nm},(L)$-phenylalanine anion has little effect on the fluorescence intensity of $(S, S)-4$ under the same condition (Figure 1 (a)). (D)-phenylalanine anion enhanced the fluorescence intensity of $(S, S)-46.29$ times more than $(L)$-phenylalanine anion did, that is, ef $=6.29$ ([ef $=$ $\left.\left(I_{\mathrm{D}}-I_{0}\right) /\left(I_{\mathrm{L}}-I_{0}\right)\right] . I_{0}$ represents the fluorescence emission intensity in the absence of the chiral substrate. $I_{\mathrm{D}}$ and $I_{\mathrm{L}}$ are the fluorescence intensities in the presence of $(D)$-substrate and $(L)$-substrate, respectively). Due to inherent chiral recognition, using the mirror sensor $(R, R)-\mathbf{4}$ instead of $(S, S)-\mathbf{4}$, a contrasting result was obtained as being expected (Figure 1 (b)). The large fluorescence increasing could be attributed to the photoinduced electron transfer (PET) mechanism. In the absence of anion, the electron-withdrawing group - $\mathrm{OH}$ decreased fluorescence intensity, when the sensors interact with the anion, the interaction was expected to turn on the fluorescence by inhibiting the PET. ${ }^{5,36,37}$

To get deep insight into the recognition system, $(R)-\mathbf{4},(S, R)-\mathbf{4}$ and $(R, S)-\mathbf{4}$ were applied to conduct the fluorescent recognition. $(R)-\mathbf{4}$ shows a selective recognition of $(L)$-phenylalanine anion, but the selectivity is weaker than that of $(R, R)-\mathbf{4}$ (Figure $1(\mathrm{c}))$. When $(S, R)-\mathbf{4}$ and $(R, S)-\mathbf{4}$ were treated with $(D)$ - or $(L)$-phenylalanine anion, as shown in Figure 1 (d) and (e), nearly the same weak fluorescence enhancement was observed, but the fluorescence enhancement did not indicate any enantioselectivity. We believe the configurations of both BINOL and ECH affect the selectivity, the building block of BINOL modified by ether and hydroxyl groups can well fit for the formation of a more stable complex of $(R, R)-\mathbf{4}+(L)$ and $(S, S)-\mathbf{4}+(D)$.

We also found that the hydroxyl groups of polyether $\mathbf{4}$ are necessary for the selective recognition of 
phenylalanine anion. As can be seen in Figure 1 (f), when it comes to $(R, R)-\mathbf{3}$ (the hydroxyl group is protected), the fluorescence is much stronger than $(R, R)-\mathbf{4}$ at the same concentration. While only very small fluorescence enhancement is observed in the presence of $(D)$ - or $(L)$-phenylalanine anion.

The effect of various concentrations of $(D)$ - and $(L)$-phenylalanine anions on the fluorescence of $(R, R)-\mathbf{4}$ at $364 \mathrm{~nm}$ was investigated (Figure 2). It can be seen that the fluorescence intensity was enhanced within the scope of the investigated concentrations. $(L)$-phenylalanine anion led to 1.5-3.25-fold increase in the fluorescence intensity of $(R, R)-4$, while $(D)$-phenylalanine anion caused little change in the fluorescence. Thus, the sensor $(R, R)-4$ proved to be highly enantioselective toward phenylalanine anion.

(a)

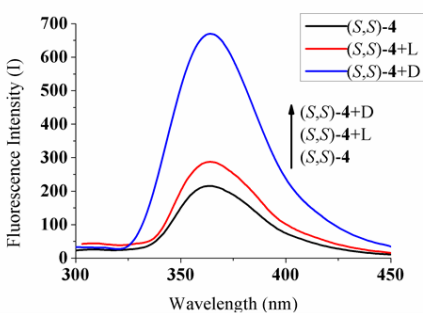

(d)

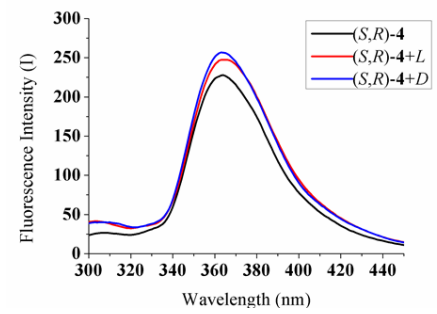

(b)

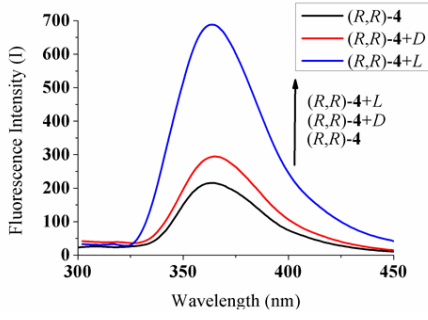

(e)

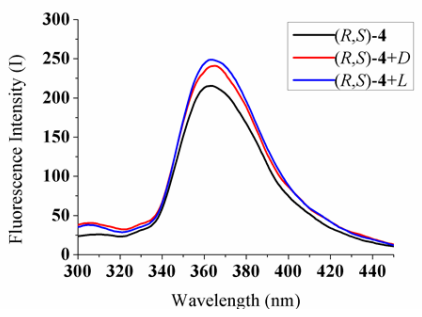

(c)

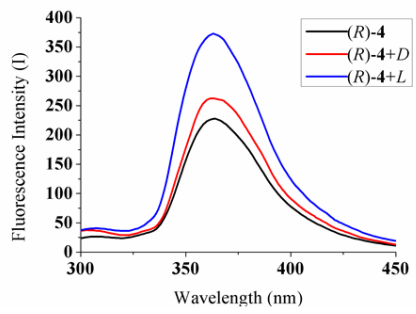

(f)

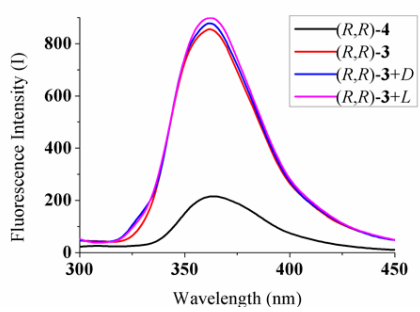

Figure 1. Fluorescence spectra of the polyethers $\left(1 \times 10^{-6} \mathrm{~mol} \cdot \mathrm{L}^{-1}\right.$ in $1: 1 \mathrm{v} / \mathrm{v} \mathrm{THF} / \mathrm{H}_{2} \mathrm{O}, 0.01 \mathrm{~mol} \cdot \mathrm{L}^{-1}$ Tris- $\mathrm{HCl}$ buffer, $\mathrm{pH}=7.4)$ with $(D)$ - and $(L)$-phenylalanine anion $\left(1 \times 10^{-4} \mathrm{~mol} \cdot \mathrm{L}^{-1}\right) . \lambda \mathrm{ex}=239 \mathrm{~nm}$, ex/em slits $=3 / 5 \mathrm{~nm}$.

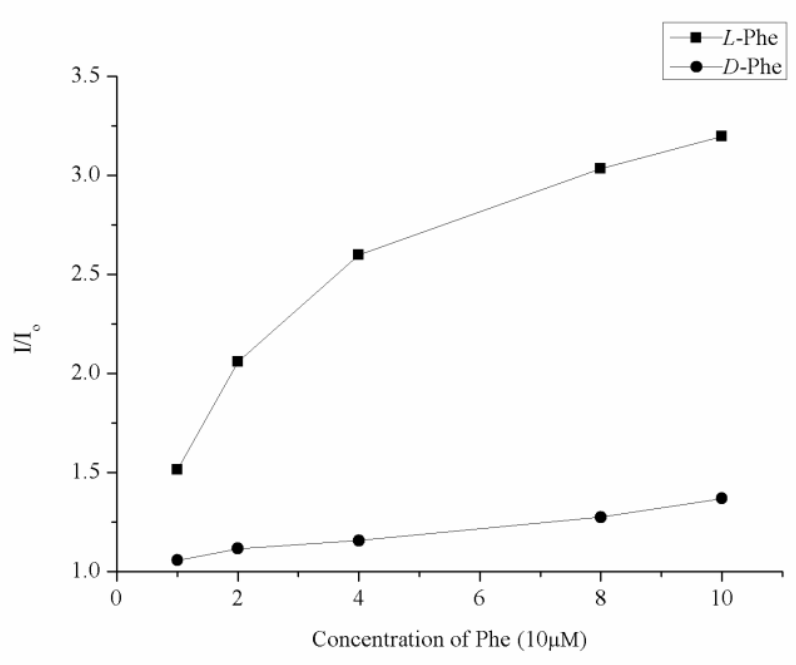

Figure 2. Fluorescence spectra of $(R, R)-4\left(1 \times 10^{-6} \mathrm{~mol} \cdot \mathrm{L}^{-1}\right.$ in $1: 1 \mathrm{v} / \mathrm{v} \mathrm{THF} / \mathrm{H}_{2} \mathrm{O}, 0.01 \mathrm{~mol} \cdot \mathrm{L}^{-1}$ Tris- $\mathrm{HCl}$ buffer, $\mathrm{pH}=7.4)$ with increasing amounts of $(D)$ - and $(L)$-phenylalanine anion $\left(1,2,4,8,10 \times 10^{-5} \mathrm{~mol} \cdot \mathrm{L}^{-1}\right) . \lambda_{\mathrm{ex}}=239 \mathrm{~nm}$, ex/em slits $=3 / 5 \mathrm{~nm}$.

\section{CONCLUSION}


Herein we have synthesized a class of fluorescence-based polyether from chiral BINOL and optical ECH. The fluorescence response of the polyether on phenylalanine anion show that polyether $(S, S)-4$ and $(R, R)-4$ exhibit greater fluorescence enhancement response toward phenylalanine anion, the value of enantiomeric fluorescence difference ratio (ef) reaches as high as 6.29. These fluorescence sensitivity and enantioselectivity make $(S, S)-\mathbf{4}$ and $(R, R)-\mathbf{4}$ practically useful sensors for the recognition of the phenylalanine anion.

\section{ACKNOWLEDGMENT}

This work was supported by the National Science Foundation of China (21172186), the Higher Education Doctoral Science Foundation of China (No. 20134301110004) and the Program for Innovative Research Cultivation Team in University of Ministry of Education of China (1337304).

\section{SUPPORTING INFORMATION AVAILABLE}

Supplementary material is available on the publisher's web site along with the published article. Charts of ${ }^{1} \mathrm{H}$ and ${ }^{13} \mathrm{C}$ NMR, CD spectra, UV-vis spectroscopy and TGA are included.

\section{REFERENCES}

1. Wang C, Wu E, Wu X, Xu X, Zhang G, Pu L. J. Am. Chem. Soc. Enantioselective Fluorescent Recognition in the Fluorous Phase: Enhanced Reactivity and Expanded Chiral Recognition. 2015; 137 (11): 3747-3750. DOI: 10.1021/ja512569m

2. Chen C, Shi H, Zhao G. J. Phys. Chem. C. Chiral Recognition and Enantioselective Photoelectrochemical Oxidation toward Amino Acids on Single-Crystalline ZnO. 2014; 118 (22): 12041-12049. DOI: 10.1021/jp502853b

3. Feng H-T, Zhang X, Zheng Y-S. J. Org. Chem. Fluorescence Turn-on Enantioselective Recognition of both Chiral Acidic Compounds and $\alpha$-Amino Acids by a Chiral Tetraphenylethylene Macrocycle Amine. 2015; 80 (16): 8096-8101. DOI: 10.1021/acs.joc.5b01194

4. Lin J, Hu Q-S, Xu M-H, Pu L. J. Am. Chem. Soc. A Practical Enantioselective Fluorescent Sensor for Mandelic Acid. 2002; 124 (10): 2088-2089. DOI: 10.1021/ja011971x

5. Xu K-x, Jiao S-y, Yao W-y, Kong H-j, Zhang J-1, Wang C-j. Sens. Actuators, B. Syntheses and highly enantioselective fluorescent recognition of $\alpha$-hydroxyl/amino carboxylic acid anions in protic solutions. 2013; 177: 384-389. DOI:

http://dx.doi.org/10.1016/j.snb.2012.11.024

6. Li Q, Xu K, Song P, Dai Y, Yang L, Pang X. Dyes. Pigm. Novel enantioselective fluorescent sensors for malate anion based on acridine. 2014; 109: 169-174. DOI:

http://dx.doi.org/10.1016/j.dyepig.2014.05.017

7. Xu K-x, Kong H-j, Zu F-1, Yang L, Wang C-j. Spectrochim. Acta, Part A. A pair of chiral fluorescent sensors for enantioselective recognition of mandelate in water. 2014; 118 :

811-815. DOI: http://dx.doi.org/10.1016/j.saa.2013.09.083

8. Liu H-L, Zhu H-P, Hou X-L, Pu L. Org. Lett. Highly Enantioselective Fluorescent Recognition of Serine and Other Amino Acid Derivatives. 2010; 12 (18): 4172-4175. DOI: $10.1021 / \mathrm{ol} 101383 \mathrm{k}$

9. He X, Cui X, Li M, Lin L, Liu X, Feng X. Tetrahedron Lett. Highly enantioselective fluorescent sensor for chiral recognition of amino acid derivatives. 2009; 50 (42): 5853-5856. 
DOI: http://dx.doi.org/10.1016/j.tetlet.2009.08.006

10. Lin J, Li Z-B, Zhang H-C, Pu L. Tetrahedron Lett. Highly enantioselective fluorescent recognition of $\alpha$-amino acid derivatives. 2004; 45 (1): 103-106. DOI:

http://dx.doi.org/10.1016/j.tetlet.2003.10.116

11. Wang F, Nandhakumar R, Hu Y, Kim D, Kim KM, Yoon J. J. Org. Chem. BINOl-Based Chiral Receptors as Fluorescent and Colorimetric Chemosensors for Amino Acids. 2013; 78 (22): 11571-11576. DOI: 10.1021/jo401789a

12. Heo J, Mirkin CA. Angew. Chem. Int. Ed. Pseudo-Allosteric Recognition of Mandelic Acid with an Enantioselective Coordination Complex. 2006; 45 (6): 941-944. DOI: 10.1002/anie.200503343

13. Mei X, Wolf C. J. Am. Chem. Soc. Enantioselective Sensing of Chiral Carboxylic Acids. 2004; 126 (45): 14736-14737. DOI: 10.1021/ja0459781

14. Seifert HM, Jiang Y-B, Anslyn EV. Chem. Commun. Exploitation of the majority rules effect for the accurate measurement of high enantiomeric excess values using CD spectroscopy. 2014; 50 (97): 15330-15332. DOI: 10.1039/C4CC07927B

15. Jo HH, Lin C-Y, Anslyn EV. Acc. Chem. Res. Rapid Optical Methods for Enantiomeric Excess Analysis: From Enantioselective Indicator Displacement Assays to Exciton-Coupled Circular Dichroism. 2014; 47 (7): 2212-2221. DOI: 10.1021/ar500147x

16. Xu M-H, Lin J, Hu Q-S, Pu L. J. Am. Chem. Soc. Fluorescent Sensors for the Enantioselective Recognition of Mandelic Acid: Signal Amplification by Dendritic Branching. 2002; 124 (47): 14239-14246. DOI: 10.1021/ja020989k

17. Lin J, Zhang H-C, Pu L. Org. Lett. Bisbinaphthyl Macrocycle-Based Highly Enantioselective Fluorescent Sensors for $\alpha$-Hydroxycarboxylic Acids. 2002; 4 (19): 3297-3300. DOI: $10.1021 / 01026565 \mathrm{c}$

18. Pugh VJ, Hu Q-S, Pu L. Angew. Chem. Int. Ed. The First Dendrimer-Based Enantioselective Fluorescent Sensor for the Recognition of Chiral Amino Alcohols. 2000; 39 (20): 3638-3641. DOI: 10.1002/1521-3773(20001016)39:20<3638::AID-ANIE3638>3.0.CO;2-G

19. Pu L. Chem. Rev. Fluorescence of Organic Molecules in Chiral Recognition. 2004; 104 (3): 1687-1716. DOI: 10.1021/cr030052h

20. Zhang X, Yin J, Yoon J. Chem. Rev. Recent Advances in Development of Chiral Fluorescent and Colorimetric Sensors. 2014; 114 (9): 4918-4959. DOI: 10.1021/cr400568b

21. Chen X, Jou MJ, Yoon J. Org. Lett. An “Off-On” Type UTP/UDP Selective Fluorescent Probe and Its Application to Monitor Glycosylation Process. 2009; 11 (10): 2181-2184. DOI: $10.1021 / 019004849$

22. Lee S, Lee KM, Lee M, Yoon J. ACS Appl. Mater. Interfaces. Polydiacetylenes Bearing Boronic Acid Groups as Colorimetric and Fluorescence Sensors for Cationic Surfactants. 2013; 5 (11): 4521-4526. DOI: 10.1021/am3030245

23. Zhu L, Anslyn EV. J. Am. Chem. Soc. Facile Quantification of Enantiomeric Excess and Concentration with Indicator-Displacement Assays: An Example in the Analyses of $\alpha$-Hydroxyacids. 2004; 126 (12): 3676-3677. DOI: 10.1021/ja031839s

24. Zhu L, Zhong Z, Anslyn EV. J. Am. Chem. Soc. Guidelines in Implementing Enantioselective Indicator-Displacement Assays for $\alpha$-Hydroxycarboxylates and Diols. 2005; 127 (12): 4260-4269. DOI: 10.1021/ja0435945

25. Yang D, Li X, Fan Y-F, Zhang D-W. J. Am. Chem. Soc. Enantioselective Recognition of 
Carboxylates: A Receptor Derived from $\alpha$-Aminoxy Acids Functions as a Chiral Shift Reagent for Carboxylic Acids. 2005; 127 (22): 7996-7997. DOI: 10.1021/ja051072z

26. Shirakawa S, Moriyama A, Shimizu S. Org. Lett. Design of a Novel Inherently Chiral Calix[4]arene for Chiral Molecular Recognition. 2007; 9 (16): 3117-3119. DOI: $10.1021 / \mathrm{ol} 071249 \mathrm{p}$

27. Pu L. Acc. Chem. Res. Enantioselective Fluorescent Sensors: A Tale of BINOL. 2012; 45 (2): 150-163. DOI: $10.1021 / \mathrm{ar} 200048 \mathrm{~d}$

28. Wu Y, Guo H, James TD, Zhao J. J. Org. Chem. Enantioselective Recognition of Mandelic Acid by a 3,6-Dithiophen-2-yl-9H-carbazole-Based Chiral Fluorescent Bisboronic Acid Sensor. 2011; 76 (14): 5685-5695. DOI: 10.1021/jo200675j

29. Zhang X, Chi L, Ji S, Wu Y, Song P, Han K, Guo H, James TD, Zhao J. J. Am. Chem. Soc. Rational Design of d-PeT Phenylethynylated-Carbazole Monoboronic Acid Fluorescent Sensors for the Selective Detection of $\alpha$-Hydroxyl Carboxylic Acids and Monosaccharides. 2009; 131 (47): 17452-17463. DOI: 10.1021/ja9060646

30. Zhang X, Wu Y, Ji S, Guo H, Song P, Han K, Wu W, Wu W, James TD, Zhao J. J. Org. Chem. Effect of the Electron Donor/Acceptor Orientation on the Fluorescence Transduction Efficiency of the d-PET Effect of Carbazole-Based Fluorescent Boronic Acid Sensors. 2010; 75 (8): 2578-2588. DOI: $10.1021 /$ jo100119y

31. Xu K, Jiao S, Yao W, Xie E, Tang B, Wang C. Chirality. Syntheses and Highly Enantioselective Fluorescent Recognition of $\alpha$-Aminocarboxylic Acid Anions Using Chiral Oxacalix[2]arene[2]bisbinaphthes. 2012; 24 (8): 646-651. DOI: 10.1002/chir.22059

32. Xu Y, Zheng L, Huang X, Cheng Y, Zhu C. Polymer. Fluorescence sensors based on chiral polymer for highly enantioselective recognition of phenylglycinol. 2010; 51 (5): 994-997. DOI: http://dx.doi.org/10.1016/j.polymer.2010.01.038

33. Vandeleene S, Verswyvel M, Verbiest T, Koeckelberghs G. Macromolecules. Synthesis, Chiroptical Behavior, and Sensing of Carboxylic Acid Functionalized Poly(phenylene ethynylene-alt-bithiophene)s. 2010; 43 (18): 7412-7423. DOI: 10.1021/ma101816z

34. Meng J, Wei G, Huang X, Dong Y, Cheng Y, Zhu C. Polymer. A fluorescence sensor based on chiral polymer for highly enantioselective recognition of phenylalaninol. 2011; 52 (2): 363-367. DOI: http://dx.doi.org/10.1016/j.polymer.2010.12.011

35. Song F, Wei G, Wang L, Jiao J, Cheng Y, Zhu C. J. Org. Chem. Salen-Based Chiral Fluorescence Polymer Sensor for Enantioselective Recognition of $\alpha$-Hydroxyl Carboxylic Acids. 2012; 77 (10): 4759-4764. DOI: 10.1021/j03005233

36. Liu H-L, Peng Q, Wu Y-D, Chen D, Hou X-L, Sabat M, Pu L. Angew. Chem. Int. Ed. Highly Enantioselective Recognition of Structurally Diverse $\alpha$-Hydroxycarboxylic Acids using a Fluorescent Sensor. 2010; 49 (3): 602-606. DOI: 10.1002/anie.200904889

37. Bissell R, Prasanna de Silva A, Nimal Gunaratne HQ, Mark Lynch PL, Maguire GM, McCoy C, Samankumara Sandanayake KRA. Fluorescent PET (photoinduced electron transfer) sensors. In: Mattay J, editor. Photoinduced Electron Transfer V, vol. 168: Springer Berlin Heidelberg, 1993. pp. 223-264. 